\title{
Görünmez Taç Sahibi İnsanların Kurumsal Özgeci Davranışlarla Örgütsel Özdeşleşmeye Ulaşma Yolları Ömer Okan FETTAHLIOĞLU ${ }^{1}$ \\ Alican AFŞAR ${ }^{2}$ \\ $\ddot{O} z$
}

Atomu parçalamak bile bilimsel çalışmalarla mümkün hale gelmesine ră̆men, insan davranış ve duygularını açıklamakta bilim bile bazı hallerde yetersiz kalmaktadır. Insana ait genellemeler, bazı verilerden hareketle yapılan çıkarımlardan ibaret kalmaktadır. Insanlar mekan ve zamana göre değişen kendi duygu ve düşüncelerini bile açıklamakta zorlanırken, işletme çatısı altında bir araya gelen çalışanların duygu ve davranışlarını analiz etmek ise daha zor hale gelmektedir. Araştırmamızda iş hayatında yer alan çalışanların özgeci davranışlara yönelik algılarının, örgütsel özdeşleşme üzerinde etkisi olup olmadı̆̆ araştırılmıştır. Hipotezleri test etmek amacı ile Ankara OSTIM’ de sanayi sektöründe faaliyet gösteren bir işletmenin 457 çalışanı ile yapılmış anket uygulaması, SPSS programı ile analiz edilmiştir. Elde edilen bulgulara göre, özgecilik davranışları ve özdeşleşme algısı arasında pozitif yönlü orta kuvvette (,444 ve ,609 arası değerler ve $p<0.01$ düzeyinde) ilişki olduğu tespit edilmiştir. Özgeciliğin özdeşleşme üzerinde \%28 $\left(R^{2}:, 284 ; \beta:, 422 ; p: 0,000\right)$ ile \%46 $\left(R^{2}:, 462 ; \beta:, 570 ; p: 0,000\right)$ oran aralığında açılklayıcı şekilde etkili olduğu sonucuna ulaşılmıştır.

Anahtar Kelimeler: Özgecilik, Özgeci Davranışlar, Özdeşleşme, Örgütsel Özdeşleşme.

JEL Sinıflandirma Kodları: D64, L20, L21.

\section{The Ways Of Reach Organizational Identification With Corporate Altruistic Behaviors Of People Who Have Invisible Crown}

\begin{abstract}
Despite split the atom is possible with scientific activities; in the explanation of human factors even science is insufficient in some state. Generalizations that belongs the human occur only from inferences that made by some data. We have difficulty to explain even our thoughts and feelings, analyzing the behavior of all employees who come together under the roof of business are becoming more difficult. In our research, it was investigated whether the perception of alturism has effect on identification behavior. Survey application that made with 457 employees of a company which working on industry sector in Ankara OSTIM for the purpose of testing hypothesis, analyzed with SPSS program. According to the findings it has been identified there is a medium strength (values between, 444 and,609 and in level of $p<0.01$ ) positive relation between the perception of altruism and identification behavior. It has been detected alturizm oriented perceptions have explanatory effect on identification behavior oriented perception with rate of between $28 \%(R 2:, 284 ; \beta:, 422 ; p: 0,000)$ to \%46 (R2:,462; $\beta:, 570 ; p: 0,000)$.
\end{abstract}

Keywords: Altruism, Identification, Organizational Identification.

JEL Classification Codes: D64, L20, L21.

1 Doç. Dr., Kahramanmaraş Sütçü İmam Üniversitesi,, İktisadi ve İdari Bilimler Fakültesi, İşletme Bölümü, ofettahlioglu@hotmail.com

2 Uzman, Kahramanmaraş Sütçü İmam Üniversitesi, Sosyal Bilimler Enstitüsü, afsarcanali@gmail.com 


\section{Ö.O.FETTAHLIOĞLU -A.AVŞAR}

\section{GİRIŞ}

İnsanlığın ilk evresinden itibaren hayatta kalma mücadelesi ile birlikte insanlar, doğa olaylarına ve diğer etmenlere karşı bir arada olma çabası içerinde olmuştur. Bir arada daha etkili sonuçların alınmasının ardından, bu birlikteliğin sonucu zamanla sosyal bir varlık haline dönüşmüşlerdir. İnsanların tek başına yapamayacağı faaliyetleri bir arada yapma eğilimi sonucunda ortaya çıkan işletme yapıları da özünde sosyal bir varlığı işaret etmektedir.

İnsanların bir arada olacağı gruplara mensup olmayı tercih etmesinde ise, söz konusu grupları, sahip oldukları kendi özelliklerine yakın özellik taşıan gruplar olarak görmesi etkili olabilmektedir. Bu açıdan bir bireyin, mensubu olduğu grubun özelliklerini benimsemesi, o grup içindeki etkinliğini ve faaliyetlerini de olumlu etkilemektedir. Bu açıdan işletmelerin son dönemlerde üzerinde fazlası ile durdukları birlik olma, takım çalışmaları, grup halinde öğrenme ve uygulama, sinerji oluşturma, örgütsel bağlılık ortaya çıkartma gibi bir çok benzeri anlayışın başarılı olabilmesi için örgütsel özdeşleşmenin sağlanabilmesi önemli bir kavram haline gelmiştir. Örgütsel özdeşleşme, çalışanların "ben” duygusundan ziyade, "biz" duygusuna sahip olmalarına etki eden bir anlayış haline gelmiştir. $\mathrm{Bu}$ duygunun yani örgütsel özdeşleşmenin ortaya çıkmasına katkı sağlayabilecek bir kavram da özgecilik davranışlarıdır.

Salt özgeci davranışların örgüte yansıması olarak düşünülebilecek örgütsel özgeci davranışların temelinde, hedonik bir tatmine ulaşma amacı yatsa dahi, diğer çalışanlara gönüllü olarak yardımcı olmak, hem örgütsel devamlılık hem de çalışanlar arası bütüncül bir yapının ortaya çıkmasında etkili olabilmektedir. Bencil davranışların karşıtı olan eylemler olarak düşündüğümüz özgeci davranışların işletme içerisinde artması, her işletmenin sahip olmak isteyeceği bir yapıdır. Bu nedenle çalışmamızda bu tür davranış sergileyen kişilerin "görünmez taç" sahibi olduklarını ve bu yolla diğer çalışanlara göre daha mutlu olduklarını düşünerek, görünmez taç kavramının söz konusu kavramlarla bir arada ele alınabileceği kanaatine sahibiz. Bu tacı takan kişilerin ise, "bencil” davranışlar yerine "sencil" davranışlar sergilediklerini düşünüyoruz. Hatta bu düşünce ile 
örgütsel özdeşleşme tanımına "çalışanların ben duygusundan arınarak, biz duygusuna sahip olmaları" ş̧eklinde bir tanımlamanın da getirilebileceğini savunuyoruz.

İşletmelerin kurulması için üretim faktörlerinin bir araya getirilmesi değil, devamlılığı sağlayabilmenin zorlaştığı günümüzde, en vazgeçilmez ve kıymet taşıyan yatırım faktörünün çalışanlar olduğu gerçeği herkes tarafından kabul edilir hale gelmiştir. $\mathrm{Bu}$ nedenle nitelikli çalışanların başka işletmelere yönelmemesi adına, çalıştıkları firmada kalmalarını sağlayacak uygulamalar, insan kaynaklarının stratejik yönetim uygulamaları arasında öncelikli olarak yerini alacak vaziyettedir. İnsan kaynakları uygulamalarına stratejik katkı sağlayabilecek uygulamaların başında ise, örgütsel özdeşleşme ve örgütsel özgecilik uygulamaları yer almaktadır. $\mathrm{Bu}$ nedenle bu iki kavramı bir arada ele alarak, örgütsel özgeciliğin, örgütsel özdeşleşme algısını arttırabileceği varsayımına dayanarak araştırma yapmanın doğru olacağı kanaatindeyiz. Bu kavramlara yönelik yapılabilecek çalışmalara farklı bir bakış açısı kazandırmak ise yegane amacımızdır. Kavramlara yönelik yazın incelemesinin ardından, alan araştırması ile elde ettiğimiz bulgular çalışmamızın bulgular kısmında açıklanacaktır.

\section{2. ÖZGECİLIK}

Özgecilik kavramı, etimolojik kökeni Latince başkası anlamına gelen "alter" sözcüğünden türetilmiş bir kavramdır. Yardım etme, elseverlik, diğergamlılık ve altruizm olarak da bilinmektedir. Kişinin kendi menfaati için değil de, başkalarının iyiliği için yapmış olduğu davranışları tanımlamak için kullanılmaktadır. Hatta bir kişinin yaşamını diğer kişilere adaması olarak da tanımlanmaktadır. Bu kapsamda özgeciliği, genel olarak bencil davranışların karşıtı olan eylemler olarak da düşünmek mümkündür. Oliner ve Oliner (1988:166)'e göre özgeci davranış sergileyen kişiler genellikle, insanlık yararına fedakarlıkta bulunan ve insanlığın faydasını gözeten kişiler olduğunu ifade etmektedirler.

İnsanlar, biyolojik ve ruhsal olmak üzere iki farklı yapıdan meydana gelmiştir. Fizyolojik ihtiyaçların karşılanması ile biyolojik haz, duygusal ihtiyaçların 


\section{Ö.O.FETTAHLIOĞLU -A.AVSAR}

karşılanması ile de ruhsal haz ortaya çıkmaktadır. Örneğin, havanın çok sıcak olduğu bir günde içi buz dolu bir meyve suyu içen bir kişi için, o meyve suyu fizyolojik bir haz ortaya çıkarırken, içeceğini bir başkası ile paylaşan kişi için, aynı meyve suyu bu defa ruhsal haz ortaya çıkarabilmektedir. Bu açıdan bakıldığında, özgeci davranışların haz elde etmek için yapılan davranışlar olduğu da düşünülebilmektedir. (Taylor vd., 2010)'e göre, özgeci davranışlar, "bir başkasına yardım etmiş olmanın verdiği haz dışında, herhangi bir karşılık ya da ödül beklentisi olmadan gönüllülük kapsamında gerçekleşen davranışlar" olarak tanılanmıştır (Taylor vd., 2010:379). Başka bir ifade ile çalışanların, diğer çalışanlara herhangi bir karşılık beklemeden gerçekleştirmiş olduğu prososyal davranışlar, özgecilik davranışının temeline dayanmaktadır (Deaux ve Wrightsman, 1988:222).

Daha çok insani yardım kuruluşları ve gönüllü kuruluşlar veya hayırseverlik gibi kavramlarla anılan özgecilik kavramının, örgütsel açıdan ele alınmaya başlanması ise, daha çok 2000'li yıllara dayanmaktadır. Çalışan bireylerin, firma içindeki başka kişilere gönüllü olarak destek olması örgütlerde özgecilik olarak tanımlanır hale gelmiştir. Bu açıdan örgütsel özgeciliği "firma içerisinde bir arada çalışan kişilerin gönüllü olarak firma faaliyetlerinde veya olası herhangi bir sorunda birbirlerine yardımcı olmak amacı ile gerçekleştirdikleri davranışlar" olarak tanımlamak mümkündür. Bu tür davranışların gerçekleştirilmesinde ise asıl amaç, örgütsel işleyişe fayda sağlamaktır.

Örgütsel özgecilik, "çalışanların, diğer işgörenlere yardım ederek onların karşılaştığ1 sorunların üstesinden gelmelerine gönüllü katk1 sağlamaları konusundaki tutum ve davranışlarını içerir” (Tutar, 2013:280). Ancak örgütsel anlamda özgecilikten bahsedebilmek için, yapılacak yardımın örgütün işleyişi ile ilgili konularda olması gerekmektedir (Podsakoff vd, 2000:516). Bu tanımlamalara bakıldığında örgütsel fayda sağlamanın, esas unsur olarak ele alındığını görmek mümkündür. Çelik (2007)'e göre, özgecilik davranışının kapsamında, çalışanların örgütlerinin yararına gönüllü olarak birbirine yardımcı olarak sergiledikleri davranışlar sergilemeleri ve işle ilgili problemleri büyümeden önce önlem almaya 
yarayacak davranışlar yer almaktadır (Çelik, 2007:128-129). Bu şekilde gerçekleşen davranışlar, uyumlu bir çalışma ortamının sağlanması, çalışanların işe yönelik motivasyonunun artması ve bu sayede iş performanslarının yükselmesi gibi faydalar ortaya çıkarabilecektir (Gürbüz, 2006:55). Bu açıklamalara bakıldığ zaman, bize göre örgütsel fayda için yapılmayan gönüllü özgecilik davranışlarının, örgütsel özgecilik kapsamında değil, salt özgecilik kapsamında ele alınması daha doğru olacaktır.

Salt özgecilik davranışları sergileyen bireyler, başkalarının yoksunluklarını gidermek için gayret göstermekte, başkalarının mutluluğunu düşünmekte ve bu düşünce ve davranışlarından dolayı da sevinç duyan merhametli ve iyi insanlar olarak tabir edilmektedirler (Öymen, 1975:46). Gerek günlük hayatta gerekse iş hayatında insanlara karşılık beklemeksizin yardım eli uzatan kişiler, toplum içerisinde daha çok sevilmekte ve bu tür kişilere karşı diğer insanlar tarafından da sempati beslenmektedir. Yardımsever insanların, insanlık yararına yaptıkları davranışlarla birer kahraman olduğunu söylemek de kanaatimizce yanlış olmayacaktır. $\mathrm{Bu}$ nedenle de bizler, bu tür kişilerin görünmez bir taç ile taçlandırıldığını, bu görünmez tacın da onlara mutluluk verdiğini düşünüyoruz. $\mathrm{Bu}$ manevi tatmin duygusunu ise "görünmez taç" kavramı ile simgelemenin doğru olacağını düşünmekteyiz. Çünkü bu tür insanlar, karşılık beklemeden başkalarına yardımcı olmayı gönüllü olarak gerçekleştirmektedirler. Davranış sonucu elde ettikleri yegane şey ise manevi tatmin duygusu olmaktadır.

Çalışma ortamlarında özgecilik davranışları, farklı şekillerde ortaya çıkabilmektedir. Örneğin, acil olarak bitirilmesi gereken bir iş konusunda iş arkadaşına yardımcı olmak, acil bir işi olup da çalışmasına kısa bir süre ara vermek durumunda olan bir çalışanın işlerini de üstlenerek, o süre zarfında çalışma arkadaşının idare edilmesi gibi davranışlar örgütsel özgeci davranışlar içerinde sayılabilir. Hatta mal ve hizmet üretiminde kendisinden beklenen düzeyin üzerinde çaba gösteren bir çalışanın davranışları dahi özgeci davranışlar arasında yer alabilmektedir. Bu gibi davranışlar, çalışanlar arası işbirliği, birlik olma duygusu, sinerji, takım ruhunun oluşması, örgütsel bağlılık gibi olumlu sonuçlar ortaya 


\section{Ö.O.FETTAHLIOĞLU -A.AVSAR}

çıkarabilmektedir. Bunların yanında işe yeni başlayan bir birey, kendisinden daha kıdemli ve uzman kişilerin yardımı ile oryantasyon sürecini saha kısa sürede tamamlayabilmektedir. İnsan davranışları temelinde gerçekleşen bu üst görev bilinci, örgütlerin kurulması ve sürdürülebilirliğinin sağlaması adına gösterilen fedakarlıklar kapsamında da düşünülebilmektedir. İnsan davranışlarının prodüktivitedeki muazzam etkisi düşünüldüğünde, günümüzde özgecilik kavramı örgütler için göz ardı edilemeyecek bir kavramdır.

Özgeciliği savunan kişiler, özgeci davranışlarda bulunan kişilerin, başkalarının haz duygusunu artırmak ve onların acılarını azaltmak için bu tür davranışlarda bulunduklarını savunmaktadırlar. $\mathrm{Bu}$ savunmaya karşılık, "Neden insanlar başkalarının acısını azaltmak veya onların mutluluğunu arttırmak için iyilik yaparlar?" sorusu akla gelebilmektedir. Özgeci bireylerin eylemleri, her ne kadar karş1lı beklentisi olmadan gerçekleşmekte olsa dahi, bireyler gerçekleştirmiş oldukları bu davranışlar karşılığında hedonik bir tatmine ulaşmaktadır. Yani özgeci davranış sergileyen insanlar, sevinç veya haz duygusu yaşamak için, başkalarına yardımda bulunmaktadır. Olaya bir de bu açıdan bakıldığ 1 zaman, eylemlerinde hazzı elde etmeyi amaçlayan günümüz insanının, bir başkası üzerinden bu hazza erişmesi, insan psikolojisinin son derece karmaşık ve değişken yapıda olduğunu gösterir niteliktedir. Bireyin sadece haz beklentisinden başka bir karşıllı beklemeden gerçekleştirdiği yardımsever eylemleri sonucunda elde ettiği haz dikkate alındığında, "sencil" olarak tanımlayabileceğimiz özgeci davranışların temelinde, aslında "bencil" düşüncelerin de var olabileceğini göz ardı etmemek gerekir. Yaşadığımız toplumun tekdüze değerleri içinde kaybolan insan, özgeci davranışlar ile mutluluğu yakalamayı amaçlamaktadır. Ama daha da önemlisi, bir sonraki mutluluk kaynağı olan hazza ulaşmayı hedeflemektedir. Durum böyle olsa dahi, özgeci davranışların gerek toplumsal gerekse iş hayatına lezzet katacağ 1 aşikardır. $\mathrm{Bu}$ nedenle de görünmez taçlar takan bu kişilerin her ortamda desteklenmesi ve onlara sahip çıkılması da özgeci bir davranış olabilecektir. 


\section{3. ÖRGÜTSEL ÖZDEŞLEŞME}

İlk insan topluluklarından bu yana, toplumsal yaşam içinde yer alan her bir birey, var olma ve bu varlığını belli bir zümrenin içerisinde sürdürme çabasında olmuştur. Kabile hayatlarında bile insanları, ateşin etrafında bir arada bulunmaya ve birlik olmaya iten bilişsel, duygusal ve davranışsal etmenler, günümüz insanının sosyal yaşantısında da etkisini sürdürmektedir.

Psikanalizin öncülerinden olan Sigmund Freud, insanın çocukluk evresinde ebeveynlerine yönelik algı ve tutumları açıklarken erkek çocukların annesine, kız çocukların babasına yöneldiğini, bu nedenle de anne veya babası ile kendi kişilik özelliklerini özdeşleştirmeye çalıştığını ifade ederek, söz konusu kavramı literatüre kazandırmıştır. (Gautam, Van Dick ve Wagner, 2004: 302) yaptıkları bir çalışmada Freud (1922)'un özdeşleşmeyi "kişinin başkalarıyla kurduğu duygusal bir bağ" olarak tanımladığını ifade etmiştir. Tolman (1943:142) ise özdeşleşmeyi "bir bireyin kendini, bir gruba ait olarak hissetmesi ve ona göre hareket etmesi" şeklinde tanımlayarak, özdeşleşmeyi örgütsel alanda kullanılabilecek bir kavram haline getirmiştir. Bu tanımlamayı destekleyecek şekilde Foote (1951:21) ise, özdeşleşme kaynağından yola çıkarak oluşturduğu motivasyon teorisinde, örgüt içerisinde bireylerin özdeşleşme eğiliminde olduklarını belirtmiş ve bu süreçte bireyin etkili bir şekilde grup ve üyelere bağlandığını söylemiştir.

Örgütsel özdeşleşme, bir bireyin belirli bir gruba mensup olması neticesinde, kendini tanımladığı sosyal özdeşleşmenin spesifik bir şekli olarak da tanımlanmaktadır (Mael ve Ashfort, 1992:105). Kendisini grubun gerçek veya sembolik bir üyesi olarak algılayan birey, özdeşleşme sayesinde 'ben kimim' sorusuna k1smen de olsa cevap verebilmektedir (Karabey ve İşcan, 2005:232). Özdeşleşmeye yönelik alan yazınında örgütsel özdeşleşmenin "bilişsel, duyuşsal, değerlendirici ve davranışsal" olmak üzere dört boyutu olduğu savunulmaktadır (Edwards, 2005: 213). Bu boyutlandırmanın yanı sıra özdeşleşmenin temelinde, "bireyin örgüt tarafından geliştirilen ve belirlenen değerlere önemli ölçüde inanması ve bunları kabul etmesi” etmeninin yer aldığı ve özdeşleşmenin, örgütsel ve bireysel amaçların birleştirilmesi ve bütünleşmesi süreci olarak tanımlandığını 


\section{Ö.O.FETTAHLIOĞLU -A.AVSAR}

(Hall vd, 1970: 176- 177) da söylemek mümkündür. Bir başka tanımlamaya göre özdeşleşme, kişinin kendisini bir sosyal grubun üyesi olarak tanımlamak için hazır oluşunu gösteren ve kalıcı olan bir durumdur (DeConinck, 2011: 618).

Yazın incelemelerinde örgütsel özdeşleşmeyi, gruplar arası davranışlar ile grup dışındakilere karşı gösterilen ayrımcı davranışların psikolojik yönünü açıklamak üzere kullanıldığını da görmek mümkündür. Bu açıdan ele alındığında özdeşleşme, Tajfel ve Turner tarafindan ortaya atılan sosyal kimlik kavramının bir unsuru olarak ele alınmaktadır. Tajfel ve Turner (1985:15)'a göre sosyal kimlik kavramı, "bireyin benlik algısının, bir sosyal gruba ya da gruplara üyelerine ilişkin bilgisinden ve bu üyeliğe yüklediği değerden ve duygusal anlamlılıktan kaynaklanan parçası" olarak tanımlamaktadır.

Sosyal kimlik kavramı açısından düşündüğümüzde, bireylere ait benliğin, bireyin dahil olduğu grubun öz değerlerine göre şekillendiğini söylemek mümkündür. Sosyal kimliğin bir unsuru olan özgecilik, dahil olunan grubun sosyal değerleri ile benimsenmesi sonucu, bu değerlere sadık kalınması ve tüm bunların ötesinde, grubun sosyal değerlerine aitlik hissetmek gibi davranışsal ve bilişsel aşamaları içermektedir. Turner (1975:5)'a göre bireyler, sosyal sınıflandırmaya bağlı olarak, ait oldukları gruplarla kendi benliğini özdeşleştirerek, diğer gruplarla sosyal karşılaştırma yapmaktadır.

Çalışma hayatının da sosyal bir alan olduğu düşündüğümüzde insanın içerisine dahil olduğu örgütün öz değerlerini benimseyerek, bulunduğu örgütle özdeşleşebildiğini söylemek mümkündür. Bu nedenle de öz grup değerlerinin farkına varabilmek için, diğer grupları kendi grubu ile karşılaştırma ve aralarındaki farklılıkları görebilmektedir. Bu farklılıkların karşılaştırılması sonucunda elde ettiği düşünce kendi grubu lehine ise, örgütsel özdeşleşme pozitif yönde etkilenmektedir. Gruplar arasındaki fark diğer grubun lehine ise, örgütle özdeşleşmesi negatif yönde etkilenmekte ve zamanla özdeşleşme süreci tersine dönebilmektedir. $\mathrm{Bu}$ açıdan bakıldığında bize göre örgütsel özdeşleşme kapsamında, bireyin mensubu olduğu grup ile diğer grupları kıyaslarken, bireyin 
duygu, düşünce ve davranışlarını negatif yönde etkileyebilecek olan içsel ve dışsal etkilere maruz kalabileceği durumunun da göz ardı edilmemesi gerekir.

Örgütsel özdeşleşme kavramı, çalışma hayatında yer alan bireylerin, kendini tanımlamada, mensubu olduğu firmayı tanımlamada ve yaptığı iş rollerini tanımlamada kullanabileceği düşünceler sonucu ortaya çıkabilmektedir. (Ashforth, Harrison ve Corley, 2008: 334)'a göre bireyler, diğer çalışanlar veya gruplarla iletişime geçerken, özdeşleşmeye ait duygu ve düşünceleri doğrultusunda iletişim şekillerini ve davranış tarzlarını belirlemektedir. Bu açıdan da özdeşleşme kavramı hem örgüt hem de çalışan bireyler için önem taşımaktadır.

Bize göre örgüt amaçları ile çalışan amaçlarını bütünleştirebilen bir yapı ortaya çıkarabilmek ve bu bütüncül yapıyı koruyabilmek adına, örgütsel özdeşleşme kavramının firmalar tarafından çok dikkatli bir şekilde ele alınması gerekmektedir. Takım çalışmalarının, yaratıcı fikirlerin, örgütsel bağlılığın ve buna benzer uygulamaların önem arz ettiği rekabet ortamında, özdeşleşmiş çalışanların "ben" duygusundan arınarak, üyesi oldukları örgütü benimseyerek "biz" duygusunu kazanmış bireyler haline gelmesi daha kolay olacaktır. Bu yönden bakıldığında ise örgütsel özdeşleşmeyi, "çalışanların ben duygusundan arınarak, biz duygusuna sahip olmaları" şeklinde de tanımlamak mümkündür.

\section{ARAŞTIRMA METODOLOJISİ}

\subsection{Amaç ve Yöntem}

Araştırmanın genel amacı, örgütlerde ortaya çıkan özdeşleşme algısının ortaya çıkmasında özgecilik davranış algılarının etkili olup olmadığını araştırmaktır. Bu kapsamda araştırmamız nicel bir araştırma olarak tasarlanmış ve alan yazınından elde edilen bulgular 1şı̆̆ında teorik yapısı oluşturulmuştur. Araştırma yapmak için ise anket yöntemi kullanılarak veriler elde edilmiş ve SPSS istatistik programı ile analizler yapılmıştır.

\subsection{Ana Külte ve Örneklem}

Araştırmanın ana kütlesi, Ankara OSTIM'de sanayi sektöründe faaliyet gösteren bir işletmenin 573 çalışanı oluşturmaktadır. Söz konusu işletmede 


\section{Ö.O.FETTAHLIOĞLU -A.AVŞAR}

çalışanlara ana kütleyi temsilen 500 adet anket formu dağıttılmış olup, 472 personelden geri dönüş $(\% 94,4)$ sağlanabilmiştir. Yetersiz bir şekilde doldurulan 15 adet form analiz kapsamına alınmamış, toplam 457 adet anket formu analiz kapsamına alınmıştır. Analiz sonucu elde edilen bulgulara göre, katılımcıların demografik özellikleri tablo 1'de yer almaktadır.

Tablo 1. Demografik Özelliklere İlişkin Bulgular

\begin{tabular}{|c|c|c|c|c|c|}
\hline Yaş & Sayı (N:457) & $\%$ & Eğitim & Sayı (N:457) & $\%$ \\
\hline 25'Ten Küçük & 4 & 0,90 & Orta Öğretim & 176 & 38,5 \\
\hline $25-35$ & 130 & 28,4 & Lise & 132 & 28,9 \\
\hline $36-45$ & 234 & 51,2 & Ön Lisans & 72 & 15,8 \\
\hline $46-55$ & 84 & 18,4 & Lisans & 59 & 12,9 \\
\hline $56-65$ & 5 & 1,1 & Lisansüstü & 18 & 3,90 \\
\hline Cinsiyet & Sayı (N:457) & $\%$ & Medeni Durum & Sayı (N:457) & $\%$ \\
\hline Erkek & 381 & 83,4 & Evli & 280 & 61,3 \\
\hline Kadın & 76 & 16,6 & Bekar & 177 & 38,7 \\
\hline
\end{tabular}

Katılımcıların yaş ortalaması daha çok 36-45 yaş ve 25-35 yaş aralığında yığılma göstermektedir. En az yığılma ise 56-65 yaş aralığındadır. Eğitim durumlarında ise, \%38,5'inin orta öğretim düzeyinde ve \%28,9'unun lise düzeyinde eğitime sahip olduğu görülmektedir. Katılımcıların \%83,4'ü erkek, \%16,6's1 kadın ve \%61,3’ü evli, \%38,7'si bekar çalışanlardan oluştuğu görülmektedir. 


\subsection{Araştırma Modeli ve Hipotezler}

Araştırmamıza ait araştırma modeli şekil 1'de sunulmuştur.

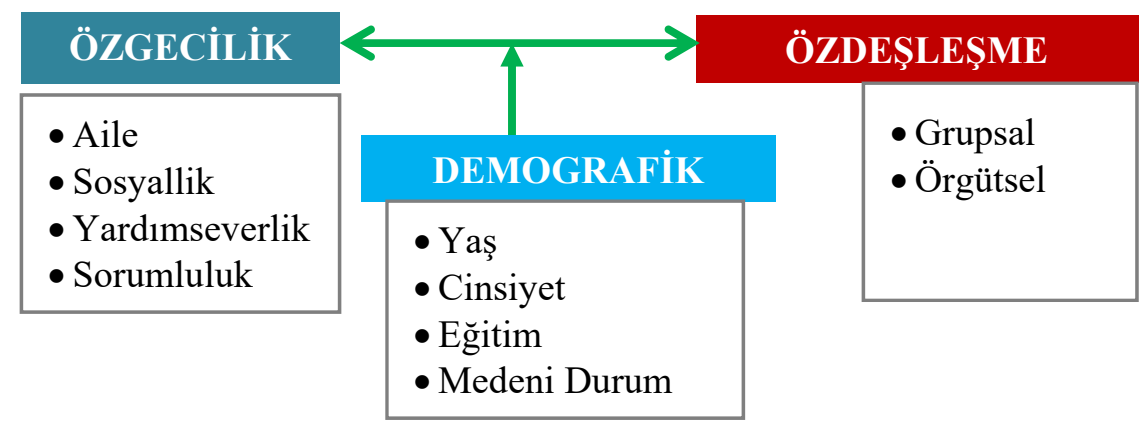

Şekil 1. Araştırma Modeli

Araştırma modeline göre aşağıdaki hipotezler test edilmek istenmiştir:

Hipotez1: "Özgecilik ile özdeşleşmenin alt boyutları arasında anlamlı bir ilişki vardır".

Hipotez²: “Özgeciliğin alt boyutlarının, özdeşleşme üzerinde etkisi vardır”.

Hipotez: "Demografik özelliklerdeki farkl11ıklar, özgeciliğin alt boyutlarında anlamlı bir farklılığa neden olur”.

Hipotez": "Demografik özelliklerdeki farkl1lıklar, özdeşleşmenin alt boyutlarında anlamlı bir farklılı̆ga neden olur".

\subsection{Araştırmada Kullanılan Veri Toplama Araçları}

Araştırmada özdeşleşmeye yönelik veri toplamak için Mael ve Ashforth (1992) tarafından geliştirilen 12 maddelik "Özdeşleşme Ölçeği” kullanılmıştır. Ölçekte 16 arası soru önermeleri "grupsal özdeşleşme" boyutunu ve 7-12 arası soru önermeleri "örgütsel özdeşleşme" boyutunu oluşmaktadır. Özdeşleşme alt boyutlarının güvenirlilik dereceleri sırası ile, 723 ve ,758 şeklindedir.

Özgecilik davranışlarını ölçmek için London ve Bower (1968) tarafından geliştirilen 20 maddelik "Özgecilik Ölçeği”" kullanılmıştır. Soru önerme gruplarından 1-5 arası "aile" boyutunu, 6-10 aras1 "sosyallik" boyutunu, 11-15 


\section{Ö.O.FETTAHLIOĞLU -A.AVSAR}

aras1 "sorumluluk" boyutunu ve 16-20 aras1 "yardımseverlik" boyutunu oluşturmaktadır. Özgecilik alt boyutlarının güvenirlilik dereceleri sırası ile ,832; ,746; ,782 ve ,754 şeklinde tespit edilmiştir.

Bunlara ek olarak anket formunda, katılımcıların "yaş, eğitim, cinsiyet ve medeni durumu" gibi demografik özelliklerini tespit etmek amaciyla 4 adet soru yer almaktadır. Ölçek soru önermeleri 5'li likert yöntemi ile hazırlanmıştır.

\section{ARAŞTIRMA BULGULARI}

\subsection{Doğrulayıcı Faktör Analizleri ve Güvenirlilik Bulguları}

Soru önermelerine faktör analizi yapabilmek adına, verilerin uygun olup olmadığını test etmek amacıyla Kaiser Meyer Olkin katsayısı ve Bartlett Sphhericitiy değerleri hesaplanmıştır. Crombach Alfa değerleri ile de soru önermelerinin kendi içinde güvenirliliğine bakılmıştır. Ayrıca her bir soru ölçeğinde yer alan önermelerin yapısal geçerliliğini tespit edebilmek adına, doğrulayıcı faktör analizi uygulanmıştır. Özgecilik ölçeğine ilişkin bulgular tablo 2'de yer almaktadır.

Tablo 2. Özgecilik Ölçeğine İlişkin Faktör Analizi ve Güvenirlilik Bulguları

\begin{tabular}{|l|c|c|c|c|}
\hline \multicolumn{1}{|c|}{$\begin{array}{c}\text { Soru Önermeleri / } \\
\text { 1:Aile, 2:Sosyallik, 3:Yardımseverlik, 4:Sorumluluk }\end{array}$} & 1 & 2 & 3 & 4 \\
\hline Akrabaların bireye yardımcı olması &, 779 & & & \\
\hline Küçük yaşlarda kardeşlere karşı sorumluluk yüklenmek &, 749 & & & \\
\hline Kişinin babasının başkalarına yardımcı olması &, 681 & & & \\
\hline Kişinin annesinin başkalarına yardımcı olması &, 608 & & & \\
\hline Aile bireylerinin birbirine yardımcı olması &, 573 & & & \\
\hline Öğrenciyken okul etkinliklerinde görev almak & &, 687 & & \\
\hline Öğrenciyken okul etkinliklerine sıklıkla katılmak & &, 559 & & \\
\hline Kulüp ve hayır kurumu gibi kuruluşlarda yer almak & &, 533 & & \\
\hline
\end{tabular}


Dokuz Eylül Üniversitesi İktisadi ve İdari Bilimler Fakültesi Dergisi Cilt:32, Sayl:2, Yll:2017, ss. 183-206

\begin{tabular}{|c|c|c|c|c|}
\hline Çevrede gerçekleşen etkinliklere sıklıkla katılmak & & 625 & & \\
\hline Görev alınan gruplarda yoğun bir hizmet vermek & & ,779 & & \\
\hline Hayır kurumlarına sıkça bağışta bulunmak & & &, 572 & \\
\hline Tatil günlerinde dahi başkalarına yardımcı olmak & & & ,640 & \\
\hline Hasta ve düşkünleri ziyaret için zaman ayırmak & & & ,601 & \\
\hline Başkaları ile eldekilerin paylaşılması & & & ,684 & \\
\hline Maddi yardım isteyenlere yardımcı olmak & & & 675 & \\
\hline $\begin{array}{l}\text { İnsanların kendi başının çaresine bakamadığına ilişkin } \\
\text { düşünce }\end{array}$ & & & & ,703 \\
\hline $\begin{array}{l}\text { İnsanların sorumluluk üstlenme isteğinin düşük } \\
\text { olduğuna inanmak }\end{array}$ & & & & ,628 \\
\hline Zor durumda kalmış olanlara yardımcı olmak & & & &, 594 \\
\hline Kişinin kendiniz için sorumluluk taşıyabilmesi & & & & ,763 \\
\hline $\begin{array}{l}\text { Başkalarına yardım edip onlar için sorumluluk } \\
\text { üstlenmek }\end{array}$ & & & & ,748 \\
\hline Açıklanan Varyans & 19,715 & 16,421 & 14,832 & 13,522 \\
\hline Güvenirlilik & ,832 & ,746 & ,782 & ,754 \\
\hline Toplam & \multicolumn{4}{|c|}{64,490} \\
\hline Kaiser Meyer Ölçek Güvenirliliği & \multicolumn{4}{|l|}{900} \\
\hline Bartlett's Küresellik Testi Ki-Kare & \multicolumn{4}{|l|}{2873,647} \\
\hline $\mathrm{Sd}$ & \multicolumn{4}{|l|}{190} \\
\hline P Değeri & \multicolumn{4}{|l|}{, 000} \\
\hline
\end{tabular}

Özgecilik algısı için kullanılan ölçekte 20 soru önermesi yer almaktadır. Alan yazınına sadık kalarak, soru önermelerine yapılan faktör analizi ile "Aile, Sosyallik, Yardımseverlik ve Sorumluluk" olmak üzere dört faktör boyutuna ulaşılmıştır. Elde edilen analiz sonuçlarına göre, en düşük faktör yükü ,533 ile en yükssek faktör yükü ,779 düzeyindedir. Toplam varyansın \%64,49’unu açıkladığ 1 tespit edilmiştir. Güvenirlilik analizi sonucu elde ettiğimiz bulgulara göre ise, 


\section{Ö.O.FETTAHLIOĞLU -A.AVSAR}

(KMO: ,900; Ki-Kare: 2873,647; Sd: 190; p: 0,000 ) özgecilik alt boyutlarının güvenirlilik dereceleri sırası ile ,832; ,746; ,782 ve ,754 şeklindedir. Güvenirlilik oranları, sosyal bilimler alanında yapılan çalışmalar için kabul edilebilir düzeydedir.

Özdeşleşme ölçeğine ilişkin bulgular tablo 3'te yer almaktadır.

Tablo 3. Özdeşleşme Ölçeğine İlişkin Faktör Analizi ve Güvenirlilik Bulguları

\begin{tabular}{|c|c|c|}
\hline Soru Önermeleri/1:Grupsal, 2:Örgütsel & 1 & 2 \\
\hline Çalışılan birimden bahsederken, “onlar” değil, "biz” diye konuşmak & ,730 & \\
\hline Çalışılan birimin başarısını kendi başarısı gibi görmek & ,703 & \\
\hline Çalışılan birim övüldüğünde, kendine yapılmış bir övgü gibi hissetmek & ,674 & \\
\hline Çalışılan birim eleştirildiğinde üzüntü duymak &, 571 & \\
\hline Çalışılan birim hakkında başkalarının düşüncelerine önem vermek & ,617 & \\
\hline Çalışılan birimle ilgili medyada kötü bir haber çıktığında üzüntü duymak & ,718 & \\
\hline Çalışılan kurumun başarısını kendi başarısı gibi görmek & &, 614 \\
\hline Çalışılan kurum övüldüğünde, kendine yapılmış bir övgü gibi hissetmek & &, 596 \\
\hline Çalışılan kurumla ilgili medyada kötü bir haber çıktığında üzüntü duymak & & ,764 \\
\hline Çalışılan kurum hakkında başkalarının düşüncelerine önem vermek & &, 770 \\
\hline Çalışılan kurumdan bahsederken, "onlar” değil, "biz" diye konuşmak & &, 721 \\
\hline Çalışılan kurum eleştirildiğinde üzüntü duymak & &, 609 \\
\hline Açıklanan Varyans & 45,826 & 22,229 \\
\hline Güvenirlilik &, 723 &, 758 \\
\hline Toplam & \multicolumn{2}{|c|}{68,055} \\
\hline Kaiser Meyer Ölçek Güvenirliliği & \multicolumn{2}{|l|}{, 846} \\
\hline Bartlett's Küresellik Testi Ki-Kare & \multicolumn{2}{|l|}{1571,613} \\
\hline $\mathrm{Sd}$ & \multicolumn{2}{|l|}{66} \\
\hline P Değeri & \multicolumn{2}{|l|}{, 000} \\
\hline
\end{tabular}


Özdeşleşme algısı için kullanılan ölçekte 12 soru önermesi yer almaktadır. Alan yazınına sadık kalarak, soru önermelerine yapılan faktör analizi ile "grupsal özdeşleşme ve örgütsel özdeşleşme" olmak üzere iki faktör boyutuna ulaşılmıştır. Elde edilen analiz sonuçlarına göre, en düşük faktör yükü ,571 ile en yüksek faktör yükü ,770 düzeyindedir. Toplam varyansın \%68,055'ini açıkladığı tespit edilmiştir. Güvenirlilik analizi sonucu elde ettiğimiz bulgulara göre ise, (KMO: ,846; KiKare: 1571,613; Sd: 66; p: 0,000 ) özdeşleşme alt boyutlarının güvenirlilik dereceleri sırası ile ,723 ve ,758 şeklindedir. Güvenirlilik oranları, sosyal bilimler alanında yapılan çalışmalar için kabul edilebilir düzeydedir.

\subsection{Değişkenlere İlişkin Tanımlayıcı Bulgular}

Değişkenlerin alt boyutlarına ilişkin tanımlayıcı bulgular tablo 4'te sunulmuştur.

Tablo 4. Değişkenlerin Alt Boyutlarına Ait Tanımlayıcı Bulgular

\begin{tabular}{|c|l|c|c|c|c|c|}
\hline Değişkenler & \multicolumn{1}{|c|}{ Alt Boyutlar } & N & Min. & Max. & X & S \\
\hline \multirow{4}{*}{ Özgecilik } & Aile & 457 & 1,60 & 5,00 & 4,00 &, 6633 \\
\cline { 2 - 7 } & Sosyallik & 457 & 2,25 & 5,00 & 4,00 &, 6153 \\
\cline { 2 - 7 } & Yardımseverlik & 457 & 1,20 & 5,00 & 4,00 &, 6267 \\
\cline { 2 - 7 } & Sorumluluk & 457 & 2,40 & 5,00 & 3,60 &, 4766 \\
\hline \multirow{2}{*}{$\begin{array}{c}\text { Örgütsel } \\
\text { Özdeşleşme }\end{array}$} & Grupsal & 457 & 1,00 & 5,00 & 4,00 &, 6119 \\
\cline { 2 - 7 } & Örgütsel & 457 & 150 & 5,00 & 4,00 &, 5824 \\
\hline
\end{tabular}

Analiz sonucunda, Özgecilik algısına ilişkin "aile alt boyutu $(X=4,00, S=.66)$; sosyallik alt boyutu $(X=4,00, S=.62)$; yardımseverlik alt boyutu $(X=4,00, S=.63)$ ve sorumluluk alt boyutu $(X=3,60, S=.48)$ ” ortalamalar tespit edilmiştir. Özdeşleşme algısına ilişkin ise "grupsal özdeşleşme alt boyutu $(X=4,00, S=.61)$ ve örgütsel özdeşleşme alt boyutu $(\mathrm{X}=4,00, \mathrm{~S}=.58)$ ” ortalamalar tespit edilmiştir. Elde edilen minimum puanlar dikkate alındığında en düşük ortalamanın grupsal özdeşleşmeye ait olduğu görülmektedir. 


\section{Ö.O.FETTAHLIOĞLU -A.AVŞAR}

Demografik özelliklere göre değişkenlerin alt boyutları arasında farklılık ortaya çıkıp çıkmadığına ilişkin tanımlayıcı istatistiki analiz yapılmış ve elde edilen bulgular tablo 5 'te sunulmuştur.

Tablo 5. Demografik Özelliklere Göre Özgecilik Algısı Alt Boyutları Arasındaki İlişki

\begin{tabular}{|l|c|c|c|c|c|c|}
\hline \multirow{2}{*}{$\begin{array}{c}\text { Demografik } \\
\text { Özellikler }\end{array}$} & \multicolumn{5}{|c|}{ Özgecilik } \\
\cline { 2 - 7 } & Aile & Sosyallik & Yardımseverlik & Sorumluluk & $\mathbf{p}$ & Sonuç \\
\hline Cinsiyet & $\mathrm{t}=, 773$ & $\mathrm{t}=, 715$ & $\mathrm{t}=, 498$ & $\mathrm{t}=, 497$ & $\mathrm{p}>0,05$ & $\mathrm{RED}$ \\
\hline Medeni Durum & $\mathrm{t}=, 509$ & $\mathrm{t}=, 077$ & $\mathrm{t}=, 437$ & $\mathrm{t}=, 138$ & $\mathrm{p}>0,05$ & $\mathrm{RED}$ \\
\hline Ĕgitim & $\mathrm{F}=, 854$ & $\mathrm{~F}=, 402$ & $\mathrm{~F}=, 971$ & $\mathrm{~F}=, 785$ & $\mathrm{p}>0,05$ & $\mathrm{RED}$ \\
\hline Yaş & $\mathrm{F}=1,179$ & $\mathrm{~F}=, 547$ & $\mathrm{~F}=, 797$ & $\mathrm{~F}=, 542$ & $\mathrm{p}>0,05$ & RED \\
\hline
\end{tabular}

Elde edilen sonuçlara göre, özgecilik algısının alt boyutları ile demografik özellikler arasında istatistiki olarak anlamlı bir ilişki olmadığı $(p>0,05)$ tespit edilmiştir. Başka bir ifade ile söylemek gerekirse, demografik özelliklerin özgeciliğin alt boyutları arasında herhangi bir farklılığa neden olmadığını söylemek mümkündür. Bu sonuçlara göre; “demografik özelliklerdeki farkl1lıklar, özgeciliğin alt boyutlarında anlamlı bir farklılı̆ga neden olur” şeklindeki Hipotez ${ }^{3}$ reddedilmiştir.

Tablo 6. Demografik Özelliklere Göre Özdeşleşme Algısı Alt Boyutları Arasındaki İlişki

\begin{tabular}{|l|c|c|c|c|}
\hline \multirow{2}{*}{$\begin{array}{c}\text { Demografik } \\
\text { Özellikler }\end{array}$} & \multicolumn{4}{|c|}{ Özdeşleşme } \\
\cline { 2 - 5 } & Grupsal & Örgütsel & $\mathrm{p}$ & Sonuç \\
\hline Cinsiyet & $\mathrm{t}=, 679$ & $\mathrm{t}=, 507$ & $\mathrm{p}>0,05$ & RED \\
\hline Medeni Durum & $\mathrm{t}=, 312$ & $\mathrm{t}=, 971$ & $\mathrm{p}>0,05$ & RED \\
\hline Ĕgitim & $\mathrm{F}=, 623$ & $\mathrm{~F}=2,136$ & $\mathrm{p}>0,05$ & RED \\
\hline Yaş & $\mathrm{F}=, 156$ & $\mathrm{~F}=, 135$ & $\mathrm{p}>0,05$ & RED \\
\hline
\end{tabular}


Dokuz Eylül Üniversitesi İktisadi ve İdari Bilimler Fakültesi Dergisi Cilt:32, Sayl:2, Yll:2017, ss. 183-206

İstatistiki sonuçlara göre özdeşleşme algısının alt boyutları ile demografik özellikler arasında istatistiki olarak anlamlı bir ilişki olmadığı $(p>0,05)$ tespit edilmiştir. Yani, demografik özelliklerin özdeşleşmenin alt boyutları arasında herhangi bir farklılığa neden olmadığını tespit edilmiştir. Sonuçlara göre; “demografik özelliklerdeki farklılıklar, özdeşleşmenin alt boyutlarında anlamlı bir farklılığa neden olur" şeklindeki Hipotez ${ }^{4}$ reddedilmiştir.

\subsection{Değişkenler Arasındaki İliş̧kilere Ait Korelasyon Sonuçları}

Değişkenlere ait korelasyon bulguları tablo 7'de sunulmuştur.

Tablo 7. Değişkenlere Ait Korelasyon Analizi Sonuçları

\begin{tabular}{|c|c|c|c|c|c|c|c|c|}
\hline \multicolumn{3}{|c|}{ Değişkenler / Alt Boyutlar } & 1 & 2 & 3 & 4 & 5 & 6 \\
\hline \multirow{8}{*}{ 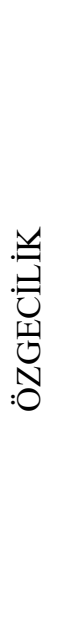 } & \multirow[t]{2}{*}{ Aile (1) } & Pearson Corr. & 1 & & & & & \\
\hline & & Sig.(2-tailed) & , 000 & & & & & \\
\hline & \multirow{2}{*}{$\begin{array}{c}\text { Sosyallik } \\
\text { (2) }\end{array}$} & Pearson Corr. &, $547^{* *}$ & 1 & & & & \\
\hline & & Sig.(2-tailed) & ,000 & ,000 & & & & \\
\hline & \multirow{2}{*}{$\begin{array}{l}\text { Sorumluluk } \\
\text { (3) }\end{array}$} & Pearson Corr. &, $518^{* *}$ &, $572^{* *}$ & 1 & & & \\
\hline & & Sig.(2-tailed) & , 000 & ,000 & ,000 & & & \\
\hline & \multirow{2}{*}{$\begin{array}{c}\text { Yardımseverlik } \\
\text { (4) }\end{array}$} & Pearson Corr. &, $448^{* *}$ &, $448^{* *}$ &, $588^{* *}$ & 1 & & \\
\hline & & Sig.(2-tailed) &, 000 & ,000 & ,000 & ,000 & & \\
\hline \multirow{4}{*}{$\begin{array}{l}\text { N } \\
\text { Nิ } \\
\text { Nิ } \\
0\end{array}$} & \multirow{2}{*}{$\begin{array}{l}\text { Grupsal } \\
\text { (5) }\end{array}$} & Pearson Corr. &, $493^{* *}$ &, $454^{* *}$ &, $625^{* *}$ &, $609^{* *}$ & 1 & \\
\hline & & Sig.(2-tailed) & ,000 & ,000 & ,000 & ,000 & ,000 & \\
\hline & \multirow{2}{*}{$\begin{array}{c}\text { Örgütsel } \\
(6)\end{array}$} & Pearson Corr. &, $444^{* *}$ &, $546^{* *}$ &, $569^{* *}$ &, $458^{* *}$ &, $547^{* *}$ & 1 \\
\hline & & Sig.(2-tailed) & ,000 & ,000 &, 000 & ,000 & ,000 & ,000 \\
\hline
\end{tabular}

${ }^{* *}$ Correlation is significant at the 0.01 level (2-tailed). $\left({ }^{* *} \mathrm{p}<0,01,{ }^{*} \mathrm{p}<0,05\right)$

Özdeşleşmenin "grupsal özdeşleşme” alt boyutu ile özgeciliğin "aile” alt boyutu $(\mathrm{r}=, 493, \mathrm{p}<0,01)$; "sosyallik" alt boyutu $(\mathrm{r}=, 454, \mathrm{p}<0,01)$ "sorumluluk" alt 


\section{Ö.O.FETTAHLIOĞLU -A.AVŞAR}

boyutu $(r=, 625, p<0,01)$ ve "yardımseverlik" alt boyutu $(r=, 609, p<0,01)$ arasında orta düzeyde, pozitif yönlü anlamlı bir ilişki olduğu tespit edilmiştir.

Özdeşleşmenin "örgütsel özdeşleşme” alt boyutu ile özgeciliğin "aile” alt boyutu ( $r=, 444, p<0,01)$; "sosyallik" alt boyutu $(r=, 546, p<0,01)$ "sorumluluk" alt boyutu $(\mathrm{r}=, 569, \mathrm{p}<0,01)$ ve "yardımseverlik" alt boyutu $(\mathrm{r}=, 458, \mathrm{p}<0,01)$ arasında orta düzeyde, pozitif yönlü anlamlı bir ilişki olduğu tespit edilmiştir.

Elde edilen bulgulara göre "Özgecilik ile özdeşleşmenin alt boyutları arasında anlamlı bir ilişki vardır " şeklindeki Hipotez ${ }^{1}$ kabul edilmiştir.

\subsection{Değişkenlere Ait Regresyon Sonuçları}

Araştırmamızda belirlemiş olduğumuz ana hipotezimiz olan özgeciliğin alt boyutlarının özdeşleşme üzerinde etkisinin olup olmadığını test etmek için regresyon analizi yapılmıştır. Analiz sonucu özgeciliğin özdeşleşme üzerinde, \%28 $\left(R^{2}:, 284 ; \beta:, 422 ; p: 0,000\right)$ ile \%46 ( $\left.R^{2}:, 462 ; \beta:, 570 ; p: 0,000\right)$ oran aralığında etkili olduğu sonucuna ulaşılmıştır. Bulgulara tablo 8 'te yer verilmiştir.

Tablo 8. Regresyon Analizi Bulguları

\begin{tabular}{|c|c|c|c|c|c|}
\hline \multirow[t]{2}{*}{ Model } & \multicolumn{4}{|c|}{ Coefficient } & \multirow{2}{*}{ Sig. } \\
\hline & Beta $(\beta)$ & S.Error & Beta $(\beta)$ & $\mathrm{t}$ & \\
\hline $\begin{array}{l}\text { Aile } \\
R=, 533^{a} R^{2}=, 284 \quad F=180,646, p=, 000\end{array}$ & ,422 &, 031 &, 533 & 13,440 & , 000 \\
\hline $\begin{array}{l}\text { Sosyallik } \\
R=, 598^{a} R^{2}=, 358 \quad F=253,783, p=, 000\end{array}$ &, 530 & ,033 & ,598 & 15,931 & ,000 \\
\hline $\begin{array}{l}\text { Yardımseverlik } \\
R=, 680^{a} R^{2}=, 462 \quad F=390,859, p=, 000\end{array}$ &, 570 & ,029 & ,680 & 19,770 & ,000 \\
\hline $\begin{array}{l}\text { Sorumluluk } \\
R=, 609^{\mathrm{a}} \mathrm{R}^{2}=, 370 \quad \mathrm{~F}=267,594, \mathrm{p}=, 000\end{array}$ & ,671 & ,041 & ,609 & 16,359 & ,000 \\
\hline \multicolumn{6}{|l|}{ a.Predictors (Contant), Özdeşleşme } \\
\hline Anova $^{\mathrm{a}}:$ Sig.;, $000^{\mathrm{b}}$ & Coefficien & $\mathrm{t}^{\mathrm{a}}$ : Sig.;, & $000^{\mathrm{b}}$ & & \\
\hline
\end{tabular}


Analiz sonuçlarına göre; çalışanlarda özdeşleşme duygusu ortaya çıkarken, aile alt boyutundan $[(\beta=, 533),(\mathrm{p}<0.01)]$, sosyallik alt boyutundan $[(\beta=, 598),(\mathrm{p}<0.01)]$, yardımseverlik alt boyutundan $[(\beta=, 680),(\mathrm{p}<0.01)]$ ve sorumluluk alt boyutundan $[(\beta=, 609),(p<0.01)]$ pozitif yönde etkilendiği tespit edilmiştir. Başka bir ifade ile açıklamak gerekirse, özgecilik alt boyutlarında ortaya çıkacak artışların, özdeşleşme algısında da pozitif yönde bir artışa neden olabileceğini ifade etmek mümkündür.

Yukarıdaki veriler ışığında, "özgeciliğin alt boyutlarının, özdeşleşme üzerinde etkisi vardır" şeklinde kurgulanan Hipotez ${ }^{2}$ kabul edilmiştir.

\section{SONUÇ ve ÖNERÍLER}

$\mathrm{Bu}$ çalışma işletmelerde çalışan bireylerin örgütsel özgecilik davranışlara yönelik algılamalarının, örgütsel özdeşleşme algısı üzerinde etkili olduğu varsayımına bağlı olarak, bu ilişkide değişkenler arası etkileşim olup olmadığ 1 ortaya koymak amacıyla yapılmıştır. Bu amaç doğrultusunda da Ankara OSTiM'de sanayi sektöründe faaliyet gösteren bir firmada 472 adet çalışanın katılımı ile anket uygulaması yapılmıştır.

Soru formu olarak kullanılan örgütsel özdeşleşme ölçeğinin doğrulayıcı faktör analizinde en düşük faktör skorunun ,571 ile en yüksek faktör skorunun ,770 düzeyinde olduğu tespit edilmiştir. Toplam varyansın \%68,055'ini açıkladığı, güvenirlilik analizine göre (KMO: ,846; Ki-Kare: 1571,613; Sd: 66; p: 0,000 ) özdeşleşme alt boyutlarının (grupsal ve örgütsel) güvenirlilik dereceleri sırası ile ,723 ve ,758 olduğu tespit edilmiştir.

Örgütsel özgecilik ölçeğinde ise, yine doğrulayıcı faktör analizinde en düşük faktör skorunun ,533 ile en yüksek faktör skorunun ,779 düzeyinde olduğu tespit edilmiştir. Toplam varyansın \%64,49'unu açıkladığı, güvenirlilik analizine göre (KMO: ,900; Ki-Kare: 2873,647; Sd: 190; p: 0,000 ) özgecilik alt boyutlarının (Aile, Sosyallik, Yardımseverlik ve Sorumluluk) güvenirlilik dereceleri sırası ile ,832; ,746; ,782 ve ,754 olduğu belirlenmiştir. 


\section{Ö.O.FETTAHLIOĞLU -A.AVSAR}

Örneklem grubunun yaş ortalaması daha çok 36-45 yaş ve 25-35 yaş aralığında yığılma gösterdiği, eğitim durumları açısından ise, \%38,5'inin orta öğretim düzeyinde ve \%28,9'unun lise düzeyinde eğitime sahip olduğu belirlenmiştir. Ayrıca örneklem grubunun \%83,4'ü erkek, \%16,6's1 kadın ve \%61,3'ü evli, \%38,7'si bekar çalışanlardan oluştuğu tespit edilmiştir.

Araştırma taslağı için oluşturulan modele göre dört ayrı hipotez test edilmiştir. Anket verilerine dayalı olarak yapılan istatistiki incelemeye göre, "Özgecilik ile özdeşleşmenin alt boyutları arasında anlamlı bir ilişki vardır” şeklinde belirlenen Hipotez $^{1}$ kabul edilmiştir. Birbirine yakın bir ilişki olabileceği düşüncesi ile oluşturulan bu hipoteze ait sonucun kabul edilmesi tarafımızdan beklenen bir sonuç olarak gerçekleşmiştir.

İkinci hipotez olarak araştırma kapsamına alınan "özgeciliğin alt boyutlarının, özdeşleşme üzerinde etkisi vardır” şeklinde kurgulanmış olan Hipotez ${ }^{2}$ yi test etmek için regresyon analizi yapılmış ve özgecilik alt boyutlarında ortaya çıkacak artışların, özdeşleşme algısında da pozitif yönde bir artışa neden olabileceği sonucuna ulaş1lmıştır. Çalışanlarda özdeşleşme duygusu ortaya çıkarken, aile alt boyutundan $[(\beta=, 533),(\mathrm{p}<0.01)]$, sosyallik alt boyutundan $[(\beta=, 598),(\mathrm{p}<0.01)]$, yardımseverlik alt boyutundan $[(\beta=, 680),(\mathrm{p}<0.01)]$ ve sorumluluk alt boyutundan

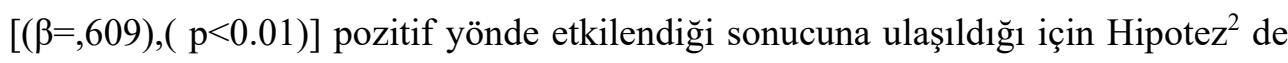
kabul edilmiştir.

Demografik özelliklerin özgeciliğin alt boyutları arasında herhangi bir farklılığa neden olup olmayacağını ortaya koymak adına, değişkenlerin alt boyutlarına ilişkin tanımlayıcı istatistik analizi yapılmış ve sonuçta "özgecilik algısının alt boyutları ile demografik özellikler arasında istatistiki olarak anlamlı bir ilişki olmadı̆̆ı" $(\mathrm{p}>0,05)$ tespit edilmiştir. Bu nedenle de, demografik özelliklerdeki farklılıklar, özgeciliğin alt boyutlarında anlamlı bir farklılığa neden olur” şeklindeki Hipotez ${ }^{3}$ reddedilmiştir. Aynı şekilde demografik özelliklerin özdeşleşmenin alt boyutları arasında herhangi bir farklılığa neden olup olmayacağını araştırmak için yapılan tanımlayıcı istatistik analizi sonucu, demografik özelliklerin özdeşleşmenin alt boyutları arasında herhangi bir farklılığa neden olmadığını tespit edilmiştir. $\mathrm{Bu}$ 
yüzden de "demografik özelliklerdeki farklılıklar, özdeşleşmenin alt boyutlarında anlamlı bir farklılığa neden olur" şeklindeki Hipotez ${ }^{4}$ reddedilmiştir.

Sonuç olarak örgüt amaçları ile çalışan amaçlarını bütünleştirebilen bir yapı ortaya çıkarabilmek ve bu bütüncül yapıyı koruyabilmek için, örgütsel özdeşleşme ve örgütsel özgecilik kavramlarının firmalar tarafından çok dikkatli bir şekilde ele alınması söz konusu firmalara fayda sağlayacaktır. Çalışanlarda "ben" duygusu yerine "biz" duygusunu kazandırabilecek bu olumlu algılamaların, rekabette aşikar bir şekilde sonuçlara yansıyabileceği de unutulmamalıdır.

Yapılan çalışmanın sadece belirli bir işletmede yapılmış olmasından dolayı, elde ettiğimiz bulguların genel olarak her işletme yapısı içinde geçerli olabileceğini söylemek mümkün değildir. Bu nedenle bundan sonraki çalışmalarda da bu konu üzerinde araştırma yapılması alan yazınına katkıda bulunabileceğini söylemek mümkündür. $\mathrm{Bu}$ nedenle çalışmamızın diğer araştırmacılara katkıda bulunmasını umut ediyoruz.

\section{KAYNAKÇA}

ASHFORTH, B.E.; HARRISON, S.H. \& CORLEY, K.G. (2008), "Identification in Organizations: An Examination of Four Fundamental Questions", Journal of Management, 34 (3), 325-374.

ÇELİK, M. (2007), Örgüt Kültürü ve Örgütsel Vatandaşlık Davranışı-Bir Uygulama, Atatürk Üniversitesi Sosyal Bilimler Enstitüsü İşletme Anabilim Dalı Yayımlanmış Doktora Tezi, Erzurum.

DEAUX, K., WRIGHTSMAN, L.S. (1988), Social Psychology (5th ed.), Pacific Grove, California: Brooks/Cole Pub. Co 


\section{Ö.O.FETTAHLIOĞLU -A.AVŞAR}

DECONINCK, B.J. (2011), "The Effects of Ethical Climate on Organizational Identification, Supervisory Trust, and Turnover Among Salespeople", Journal of Business Research, 64, 617-624.

EDWARDS, M.R. (2005), "Organizational Identification: A Conceptual and Operational Review", International Journal of Management Reviews, 7 (4), 207-230.

FOOTE, N.N. (1951), "Identification As The Basis For a Theory of Motivation", American Sociological Review, 16 (1), 14-21.

GAUTAM, T., VAN DICK, R., WAGNER, U. (2004), “Organizational Identification and Organizational Commitment: Distinct Aspects of Two Related Concepts", Asian Journal of Social Psychology, 7(3), 301-315.

GÜRBÜZ, S. (2006), “Örgütsel Vatandaşlık Davranışı İle Duygusal Bağl11ı Arasındaki İlişkilerin Belirlenmesine Yönelik Bir Araştırma”, İstanbul Üniversitesi Sosyal Bilimler Enstitüsü Ekonomik ve Sosyal Araştırmalar Dergisi, 3 (1), 48-75.

HALL, D.T., SCHNEIDER, B., NYGREN, H.T. (1970), "Personal Factors in Organizational Identification”, Administrative Science Quarterly, 15 (2), 176190.

KARABEY, C. N., İşCAN, Ö.F. (2007), “Örgütsel Özdeşleşme, Örgütsel İmaj ve Örgütsel Vatandaşlık Davranışı İlişkisi: Bir Uygulama”, Atatürk Üniversitesi İktisadi ve İdari Bilimler Dergisi, 21 (2), 231-241. 
LONDON, P., BOWER, R.K. (1968), “Altruism, Extraversion, and Mental Illness", The Journal of Social Psychology, 76, 19-30.

MAEL, F., ASHFORTH, B.E. (1992), “Alumni and Their Alma Mater: A Partial Test of the Reformulated Model of Organizational Identification", Journal of Organizational Behavior, 13(2), 103-123.

OLINER, S.P. \& OLINER, P.M. (1988), The Altruistic Personality: Rescuers of Jews in Nazi Europe, The Free Press, New Jersey.

ÖYMEN, M.R. (1975), Psikoloji Sosyoloji ve Pedagoji Açısından Ahlak Eğitimi, İstanbul: Murat Matbaacılık.

PODSAKOFF, P.M., MACKENZIE, S.B., PAINE, J.B., BACHRACH, D.G. (2000), “Organizational Citizenship Behaviors: A Critical Review Of The Theoretical And Empirical Literature and Suggestions For Future Research"., Journal of Management, 26, 513-563.

TAJFEL, H., TURNER, J.C. (1985); “The Social Identity Theory Of Intergrup Behaviour", http://faculty.kent.edu/updegraffj/gradsocial/readings/tajfel.pdf

TAYLOR, S.E., PEPLAU, L.A., SEARS, D.O. (2010), Sosyal Psikoloji, (Çev. A. Dönmez), İstanbul: İmge Kitabevi Yayınları. 


\section{Ö.O.FETTAHLIOĞLU -A.AVŞAR}

TOLMAN, E.C. (1943), “Identification And The Post-War World”, Psychological Review, 38(2): 141-148.

TURNER, J.C. (1975), "Social Comparison and Social Identity: Some Prospects for Intergroup Behaviour”, European Journal of Social Psychology, 5, 5-34.

TUTAR, H. (2013), İşletme \& Yönetim Terimleri, Ansiklopedik Sözlük, Detay Yayınc1lik, Ankara. 688s. 